\title{
Sistem Pengatur Tegangan Otomatis : Analisa Peralihan dengan Pengendali Tunggal dan Kaskade
}

\author{
Heru Dibyo Laksono ${ }^{1}$, Novizon ${ }^{1}$, Melda Latif ${ }^{1}$, Eko Amri Gunawan $^{1}$, Reri Afrianita ${ }^{2}$ \\ ${ }^{1}$ Jurusan Teknik Elektro, Fakultas Teknik Universitas Andalas \\ ${ }^{2}$ Jurusan Teknik Lingkungan, Fakultas Teknik Universitas Andalas \\ herudibyolaksono@eng.unand.ac.id
}

\begin{abstract}
ABSTRAK
Tulisan ini membahas desain dan analisa respon peralihan tegangan sistem pengatur tegangan otomatis tipe arus searah dengan pengendali tunggal dan kaskade. Sistem pengatur tegangan otomatis direpresentasikan dalam bentuk fungsi alih. Untuk pengendali tunggal dan kaskade dirancang dengan menggunakan arsitektur paralel dengan bantuan perangkat lunak Matlab dengan menggunakan kriteria desain yang sudah ditetapkan. Adapun tipe pengendali yang digunakan terdiri Proporsional (P), Integal (I), Proporsional Diferensial (PD), Proporsional Integral (PI), Proporsional Integral Diferensial (PID), Proporsional Diferensial Dengan Filter Orde Satu Pada Bagian Diferensial (PDF) dan Proporsional Intregral Diferensial Dengan Filter Orde Satu Pada Bagian Diferensial (PIDF). Untuk analisa peralihan, parameter yang dihitung terdiri waktu naik, waktu puncak, waktu keadaan mantap, nilai lewatan maksimum dan nilai puncak. Hasil analisa memperlihatkan bahwa pengendali yang memenuhi kriteria desain adalah pengendali PD dan pengendali PDF untuk pengendali tunggal dan pengendali kaskade. Untuk pengendali tunggal, nilai konstanta $\mathrm{K}_{\mathrm{p}}$ sebesar 0,6280 dan nilai konstanta $K_{D}$ sebesar 0,1710 untuk pengendali PD. Nilai konstanta $K_{p}$ sebesar 0,6130, nilai konstanta $K_{D}$ sebesar 0,1710 dan nilai konstanta $T_{f}$ sebesar 0,0009 untuk pengendali PDF. Untuk pengendali kaskade dan tipe pengendali (PD), nilai konstanta $K_{p}$ sebesar 1,7300 dan nilai konstanta $K_{D}$ sebesar 0,0242 untuk lingkar dalam $\left(\mathrm{C}_{2}\right)$. Untuk pengendali lingkar luar $\left(\mathrm{C}_{1}\right)$, nilai konstanta $\mathrm{K}_{\mathrm{p}}$ sebesar 179,0000 dan nilai konstanta $\mathrm{K}_{\mathrm{D}}$ sebesar 2,4600. Untuk pengendali kaskade dan jenis pengendali PDF, nilai konstanta $K_{p}$ sebesar 1,5900, nilai konstanta $K_{D}$ sebesar 0,0246 , nilai konstanta $T_{f}$ sebesar 0,0018 untuk lingkar dalam $\left(C_{2}\right.$. Untuk pengendali lingkar luar $\left(\mathrm{C}_{1}\right)$, nilai konstanta $\mathrm{K}_{\mathrm{p}}$ sebesar 134,0000, nilai konstanta $K_{D}$ sebesar 2,2900 dan nilai konstanta $\mathrm{T}_{\mathrm{f}}$ sebesar 0,00008 .
\end{abstract}

kata kunci : sistem pengatur tegangan otomatis, analisa peralihan, pengendali tunggal, pengendali kaskade

\section{PENDAHULUAN}

Pada zaman modern ini konsumsi akan energi listrik sangat besar sekali dalam berbagai bidang skala bidang kehidupan. Mulai dari rumah tangga, industri skala kecil, industri skala menengah dan industri skala besar memerlukan energi listrik untuk aktivitasnya dalam kehidupan sehari - hari.

Untuk suplai kebutuhan energi listrik yang sangat besar pada konsumen maka diperlukan banyak pembangkit listrik yang nantinya harus memberikan pelayanan secara kontinu. Beban yang berubah setiap saat ini menyebabkan pusat - pusat pembangkit harus siap selalu memenuhi kebutuhan energi listrik pada sisi konsumen. Tidak samanya antara daya yang dibangkitkan dengan daya yang dikosumsi oleh konsumen merupakan kendala utama yang sering dialami dalam operasi sistem tenaga listrik. Hal ini dikarenakan daya yang tersedia ditentukan oleh kemampuan daya terpasang pada unit - unit pembangkit yang terkoneksi ke sistem dan kesiapan operasi pembangkit tersebut.

Hal yang paling urgensi dalam proses pembangkitan energi listrik adalah kestabilan kinerja pembangkit dalam hal ini generator untuk memenuhi kebutuhan energi listrik pada beban. Kestabilan tegangan yang dihasilkan oleh generator dipengaruhi oleh perubahan daya reaktif. Untuk kompensasi kebutuhan daya reaktif dari beban yang berubah - ubah menyebabkan tegangan keluaran juga harus diubah - ubah agar tegangan generator berada dalam keadaan stabil. Agar keadaan tersebut bisa tercapai maka digunakan sebuah peralatan yang dapat mengendalikan tegangan keluaran generator. Pengendalian dilakukan dengan cara mengatur arus eksitasi pada generator secara otomatis. Alat ini dikenal dengan sistem pengatur tegangan otomatis. Sistem pengatur tegangan otomatis adalah suatu sistem yang digunakan untuk menjaga tegangan keluaran generator agar bersifat stabil dengan mengatur arus eksitasi.

Ada beberapa tipe sistem pengatur tegangan otomatis diantaranya sistem pengatur tegangan otomatis tipe arus searah, sistem pengatur tegangan otomatis tipe Arus searah dengan rate output feedback, sistem pengatur tegangan otomatis tipe arus searah dengan transient gain 
reduction dan sistem pengatur tegangan otomatis tipe arus searah tipe Arus statik [1]. Tipe - tipe sistem pengatur tegangan otomatis ini mempuyai respon peralihan yang berbeda - beda. Untuk analisa peralihan dimana waktu naik, waktu puncak dan waktu keadaan mantap, model sistem pengatur tegangan otomatis tipe statik memiliki nilai yang paling kecil dan untuk lewatan maksimum dan nilai puncak, model sistem pengatur tegangan otomatis tipe arus searah dengan Transient Gain Reduction memiliki nilai yang paling kecil [1]. Hasil analisa juga memperlihatkan bahwa sistem pengatur tegangan otomatis tipe arus searah memiliki respon peralihan yang kurang memuaskan. Untuk itu dalam dalam penelitian akan dibatasi pada desain dan analisa respon peralihan sistem pengatur tegangan otomatis.

Beberapa kajian yang sudah dilakukan oleh para penelitian lain diantarannya [2], peneliti ini membahas tentang respon peralihan terhadap masukan undak satuan, respon dalam domain frekuensi dan sensitivitas terhadap perubahan parameter dari sistem pengatur tegangan otomatis tipe arus searah. Hasil dari kajian ini diperoleh informasi bahwa pengendali PIDD2 mempuyai respon peralihan yang lebih baik. [3], meneliti tentang desain pengendali PID dengan algoritma Particle Swarm Optimization (PSO) berdasarkan analisa peralihan dan hasil yang diperoleh kurang memuaskan terutama untuk kecepatan frekeuensi. Atas dasar penjelasan diatas maka dalam penelitian ini dilakukan desain dan analisa respon peralihan sistem sistem pengatur tegangan otomatis dengan pengendali tunggal dan pengendali kaskade.

Penelitian ini bertujuan untuk mendapatkan informasi peralihan dari respon tegangan sistem pengatur tegangan otomatis tanpa dan dengan pengendali tunggal dan kaskade serta jenis pengendali yang memenuhi kriteria perancangan. Dalam penelitian ini, ruang lingkup pembahasan dibatasi dianataranya hubungan pembebanan pada saluran tidak dibahas pada penelitian. Model sistem pengatur tegangan otomatis untuk simulasi adalah model sistem pengatur tegangan otomatis tipe arus searah. Representasi dari sistem pengatur tegangan otomatis dinyatakan dalam bentuk fungsi alih. Tipe Pengendali yang digunakan untuk lingkar dalam dan lingkar luar pada pengendali kaskade sama dan Pemodelan, desain dan analisa sistem sistem pengatur tegangan otomatis ini dilakukan dengan Matlab.

\section{MATERI DAN METODE}

Bagian ini mendeskripsikan model matematis elemen - elemen sistem pengatur tegangan otomatis, pengendali tunggal, pengendali kaskade dan analisa peralihan. Model matematis elemen - elemen sistem pengatur tegangan otomatis ini direpresentasikan dalam bentuk fungsi alih orde satu yang terdiri dari model amplifier, model eksiter dan model generator. Untuk model amplifier dinyatakan dengan persamaan (1) berikut [4]

$$
\mathrm{G}_{\mathrm{a}}(\mathrm{s})=\frac{\mathrm{K}_{\mathrm{A}}}{1+\tau_{\mathrm{A}} \mathrm{s}}
$$

dimana $\mathrm{K}_{\mathrm{A}}$ adalah konstanta penguatan amplifier dengan jangkauan nilai dari 10 sampai 400 dan $\tau_{\mathrm{A}}$ adalah konstanta waktu amplifier dengan jangkauan nilai dari 0.02 detik sampai 0.10 detik [2]. Untuk model eksiter dinyatakan dengan persamaan (2) berikut [2]

$$
\mathrm{G}_{\mathrm{e}}(\mathrm{s})=\frac{\mathrm{K}_{\mathrm{E}}}{1+\tau_{\mathrm{E}} \mathrm{s}}
$$

dimana $\mathrm{K}_{\mathrm{E}}$ adalah konstanta penguatan eksiter dengan jangkauan nilai dari 1 sampai 10 dan $\tau_{\mathrm{E}}$ adalah konstanta waktu eksiter dengan jangkauan nilai dari 0.4 detik sampai 1.00 detik. Untuk model generator dideskripsikan dengan persamaan (3) berikut [4]

$$
\mathrm{G}_{\mathrm{G}}(\mathrm{s})=\frac{\mathrm{K}_{\mathrm{G}}}{1+\tau_{\mathrm{G}} \mathrm{s}}
$$

dimana $\mathrm{K}_{\mathrm{G}}$ adalah konstanta penguatan generator dengan jangkauan nilai dari 0.70 sampai 1 dan $\tau_{\mathrm{G}}$ adalah konstanta waktu generator dengan jangkauan nilai dari 1 sampai 2 detik pada kondisi beban nol sampai kondisi beban penuh [5]. Untuk selanjutnya masing - masing elemen sistem pengatur tegangan otomatis ini digabungkan satu sama lain sehingga terbentuk diagram blok kendali sistem pengatur tegangan otomatis yang ditampilkan pada Gambar 1 berikut

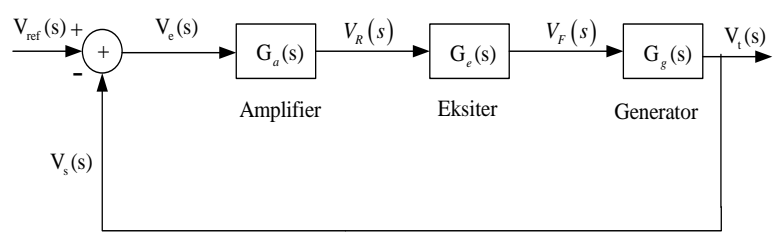

Gambar 1. Diagram Blok Sistem Pengatur Tegangan Otomatis[4]

Fungsi alih lingkar terbuka dan fungsi alih lingkar tertutup dari sistem pengatur tegangan otomatis diperoleh berdasarkan Gambar 1. Untuk fungsi alih lingkar terbuka sistem pengatur tegangan otomatis ditampilkan pada persamaan (4) berikut

$$
\mathrm{G}(\mathrm{s}) \mathrm{H}(\mathrm{s})=\mathrm{G}_{\mathrm{a}}(\mathrm{s}) \mathrm{G}_{\mathrm{e}}(\mathrm{s}) \mathrm{G}_{\mathrm{G}}(\mathrm{s})
$$

Untuk fungsi alih lingkar tertutup sistem pengatur tegangan otomatis ditampilkan pada persamaan (5) berikut

$$
\frac{V_{t}(s)}{V_{r e f}(s)}=\frac{G_{a}(s) G_{e}(s) G_{G}(s)}{1+G_{a}(s) G_{e}(s) G_{G}(s)}
$$


Untuk diagram blok kendali sistem pengatur tegangan otomatis dengan pengendali tunggal diperlihatkan pada Gambar 2 berikut

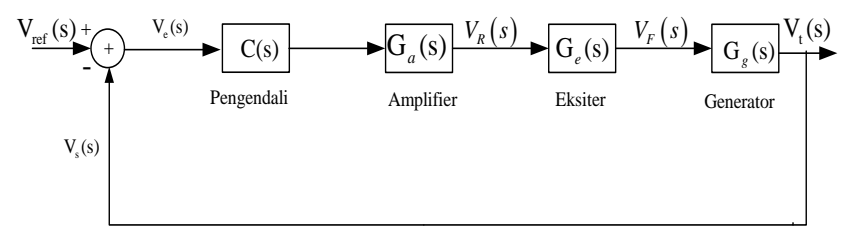

Gambar 2. Diagram Blok Sistem Pengatur Tegangan Otomatis Dengan Pengendali Tunggal [4]

Berdasarkan Gambar 2 diperoleh informasi fungsi alih lingkar terbuka sistem pengatur tegangan otomatis dengan pengendali tunggal yang diperlihatkan pada persamaan (6) berikut

$$
\mathrm{G}(\mathrm{s}) \mathrm{H}(\mathrm{s})=\mathrm{C}(\mathrm{s}) \mathrm{G}_{\mathrm{a}}(\mathrm{s}) \mathrm{G}_{\mathrm{e}}(\mathrm{s}) \mathrm{G}_{\mathrm{G}}(\mathrm{s})
$$

serta informasi fungsi alih lingkar tertutup sistem pengatur tegangan otomatis tipe arus dengan pengendali tunggal yang diperlihatkan pada persamaan (7) berikut

$$
\frac{\mathrm{V}_{\mathrm{t}}(\mathrm{s})}{\mathrm{V}_{\text {ref }}(\mathrm{s})}=\frac{\mathrm{C}(\mathrm{s}) \mathrm{G}_{\mathrm{a}}(\mathrm{s}) \mathrm{G}_{\mathrm{e}}(\mathrm{s}) \mathrm{G}_{\mathrm{G}}(\mathrm{s})}{1+\mathrm{C}(\mathrm{s}) \mathrm{G}_{\mathrm{a}}(\mathrm{s}) \mathrm{G}_{\mathrm{e}}(\mathrm{s}) \mathrm{G}_{\mathrm{G}}(\mathrm{s})}
$$

Untuk diagram blok kendali sistem pengatur tegangan otomatis dengan pengendali kaskade diperlihatkan pada Gambar 3 berikut

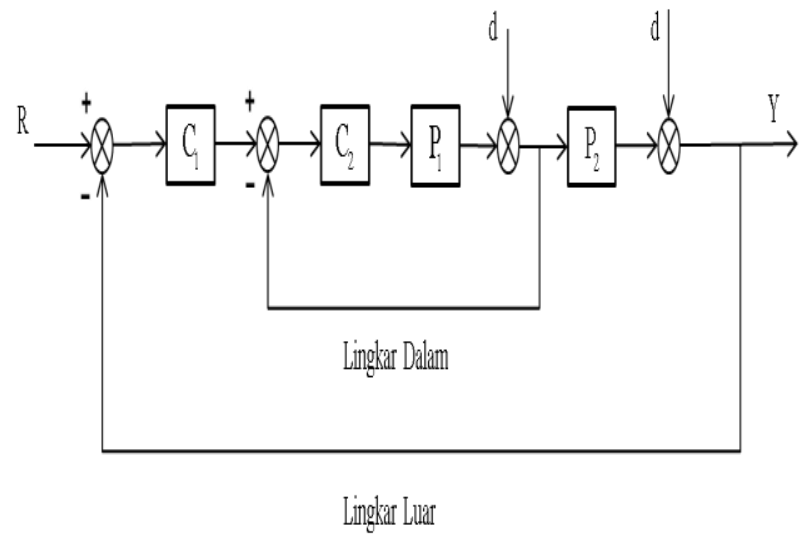

Gambar 3. Diagram Blok Pengendali Kaskade [5]

Untuk pengendali lingkar dalam $\left(\mathrm{C}_{2}\right)$ dan lingkar luar $\left(\mathrm{C}_{1}\right)$ dinyatakan dalam bentuk persamaan (8) berikut

$$
C_{2}(s)=\left[K_{p}+\frac{K_{i}}{s}+\frac{K_{d} s}{T_{f} s+1}\right]
$$

dimana $\mathrm{K}_{\mathrm{p}}$ adalah konstanta Proporsional, $\mathrm{K}_{\mathrm{i}}$ adalah konstanta integral, $K_{d}$ adalah konstanta diferensial dan $T_{f}$ adalah konstanta filter orde satu.

Pengendali P, I, PI, PD, PID, PDF dan PIDF adalah tipe pengendali yang digunakan dalam penelitian. Waktu naik, waktu puncak, waktu keadaan mantap, nilai puncak dan lewatan maksimum merupakan parameter yang dihitung dalam analisa peralihan. Rumusan perhitungan parameter respon peralihan ini bisa didapatkan dari referensi [6-9].

Pada bagian ini akan ditampilkan data - data parameter sistem pengatur tegangan otomatis, kriteria desain serta prosedur analisa peralihan respon tegangan sistem sistem pengatur tegangan otomatis dengan pengendali tunggal dan pengendali kaskade.

Pada Tabel 1 diperperlihatkan nilai parameter yang digunakan sistem pengatur tegangan otomatis [2]

Tabel 1. Nilai Parameter Sistem Pengatur Tegangan Otomatis

\begin{tabular}{cc}
\hline Parameter & Nilai \\
\hline $\mathrm{K}_{\mathrm{a}}$ & 40,0000 \\
$\mathrm{~T}_{\mathrm{a}}$ & 0,0500 \\
$\mathrm{~K}_{\mathrm{e}}$ & 1,0000 \\
$\mathrm{~T}_{\mathrm{e}}$ & 0,5000 \\
$\mathrm{~K}_{\mathrm{g}}$ & 0,8000 \\
$\mathrm{~T}_{\mathrm{g}}$ & 1,0000 \\
\hline
\end{tabular}

Data - data pada Tabel 1 kemudian disubstitusikan ke persamaan (1) s/d (3) kemudian digabungkan dengan persamaan (4) dan (5) serta diperoleh fungsi alih lingkar terbuka dan lingkar tertutup sistem pengatur tegangan otomatis tanpa pengendali yang dinyatakan dalam bentuk persamaan (9) dan (10) berikut

$$
\begin{aligned}
& \mathrm{G}(\mathrm{s}) \mathrm{H}(\mathrm{s})=\frac{32.00}{0.0250 \mathrm{~s}^{3}+0.5750 \mathrm{~s}^{2}+1.55 \mathrm{~s}+1.00} \\
& \frac{\mathrm{V}_{\mathrm{t}}(\mathrm{s})}{\mathrm{V}_{\text {ref }}(\mathrm{s})}=\frac{32.00}{0.0250 \mathrm{~s}^{3}+0.5750 \mathrm{~s}^{2}+1.55 \mathrm{~s}+33.00}
\end{aligned}
$$

Untuk desain pengendali tunggal dan kaskade dilakukan dengan kriteria desain sebagai berikut

1. Untuk waktu naik ditetapkan kurang dari 0,1465 detik.

2. Untuk waktu puncak ditetapkan kurang dari 0,4561 detik.

3. Untuk waktu keadaan mantap ditetapkan kurang dari 2,5000 detik.

4. Untuk nilai puncak ditetapkan kurang dari 1,2000.

5. Untuk nilai lewatan maksimum yang ditetapkan kurang dari $20,0000 \%$.

Pemodelan matematis sistem pengatur tegangan otomatis merupakan langkah awal dalam penelitian ini. Hasil dari pemodelan matematis sistem pengatur tegangan otomatis dalam bentuk persamaan linear 
diferensial orde 3. Dengan menggunakan transformasi Laplace dan kondisi batas, persamaan linear diferensial ini diubah dari domain waktu ke domain frekuensi. Hasil dari transformasi Laplace ini diperoleh fungsi alih lingkar terbuka dan fungsi alih lingkar tertutup dengan tegangan referensi sebagai masukan dan tegangan terminal sebagai keluaran.

Selanjutnya dilakukan analisa respon peralihan keluaran sistem pengatur tegangan otomatis dengan menggunakan fungsi alih lingkar tertutup tanpa pengendali. Berdasarkan hasil analisa ini kemudian ditentukan kriteria desain pengendali.

Setelah kriteria desain ditentukan kemudian dilanjutkan dengan desain pengendali untuk sistem pengatur tegangan otomatis. Disain pengendali dilakukan dengan bantuan Matlab. Adapun tipe pengendali yang didisain terdiri pengendali P, I, PI, PD, PID, PDF dan PIDF. Hasil desain berupa fungsi alih pengendali untuk pengendali tunggal dan pengendali kaskade.

Fungsi alih dari masing - masing pengendali kemudian digabung ke fungsi alih lingkar tertutup sistem pengatur tegangan otomatis sehingga diperoleh fungsi alih lingkar tertutup dengan pengendali. Hal ini dilakukan untuk pengendali tunggal dan pengendali kaskade. Selanjunya dengan menggunakan fungsi alih lingkar tertutup dengan pengendali maka dilakukan kembali analisa peralihan respon peralihan keluaran sistem pengatur tegangan otomatis. Hasil analisa untuk tanpa dan dengan pengendali ini kemudian dibandingkan berdasarkan kriteria desain dan didapatkan informasi pengendali yang memenuhi kriteria desain untuk sistem pengatur tegangan otomatis.

\section{HASIL DAN PEMBAHASAN}

Bagian ini mendeskripsikan hasil desain pengendali tunggal, pengendali kaskade, perbandingan analisa peralihan respon tegangan sistem pengatur tegangan otomatis dengan pengendali tunggal dan pengendali kaskade serta grafik respon peralihan tegangan sistem pengatur tegangan otomatis dengan pengendali tunggal dan pengendali kaskade terhadap masukan undak satuan.

Hasil desain pengendali untuk sistem pengatur tegangan otomatis dengan pengendali tunggal diperlihatkan pada Tabel 2 berikut

Tabel 2. Hasil Desain Pengendali Tunggal

\begin{tabular}{lcccc}
\hline Pengendali & $\mathrm{K}_{\mathrm{P}}$ & $\mathrm{K}_{\mathrm{i}}$ & $\mathrm{K}_{\mathrm{d}}$ & $\mathrm{T}_{\mathrm{f}}$ \\
\hline $\mathrm{P}$ & 0,1440 & - & - & - \\
\hline
\end{tabular}

\begin{tabular}{lcccc}
\hline I & - & 0,0117 & - & - \\
PI & 0,0662 & 0,0404 & - & - \\
PD & $\mathbf{0 , 6 2 8 0}$ & - & $\mathbf{0 , 1 7 1 0}$ & - \\
PID & 0,0697 & 0,0649 & 0,0182 & - \\
PDF & $\mathbf{0 , 6 1 3 0}$ & - & $\mathbf{0 , 1 7 1 0}$ & $\mathbf{0 , 0 0 0 9}$ \\
PIDF & 0,0694 & 0,0645 & 0,0175 & 0,0058 \\
\hline
\end{tabular}

Hasil desain pengendali untuk sistem pengatur tegangan otomatis dengan pengendali kaskade diperlihatkan pada Tabel 3. dan Tabel 4. berikut

Tabel 3. Hasil Desain Untuk Pengendali Lingkar Dalam $\left(\mathrm{C}_{2}\right)$ Pada Pengendalli Kaskade

\begin{tabular}{lcccc}
\hline Pengendali & $\mathrm{K}_{\mathrm{P}}$ & $\mathrm{K}_{\mathrm{i}}$ & $\mathrm{K}_{\mathrm{d}}$ & $\mathrm{T}_{\mathrm{f}}$ \\
\hline $\mathrm{P}$ & 0,2430 & - & - & - \\
$\mathrm{I}$ & - & 0,0287 & - & - \\
PI & 0,0354 & 0,1450 & - & - \\
PD & $\mathbf{1 , 7 3 0 0}$ & - & $\mathbf{0 , 0 2 4 2}$ & - \\
PID & 0,0439 & 0,1410 & 0,00233 & - \\
PDF & $\mathbf{1 , 5 9 0 0}$ & - & $\mathbf{0 , 0 2 4 5}$ & $\mathbf{0 , 0 0 1 8}$ \\
PIDF & 0,0408 & 0,1360 & 0,0009 & 0,0260 \\
\hline
\end{tabular}

Tabel 4. Hasil Desain Untuk Pengendali Lingkar Luar . $\left(\mathrm{C}_{1}\right)$ Pada Pengendalli Kaskade

\begin{tabular}{lcccc}
\hline Pengendali & $\mathrm{K}_{\mathrm{P}}$ & $\mathrm{K}_{\mathrm{i}}$ & $\mathrm{K}_{\mathrm{d}}$ & $\mathrm{T}_{\mathrm{f}}$ \\
\hline $\mathrm{P}$ & 13,2000 & - & - & - \\
$\mathrm{I}$ & - & 0,3630 & - & - \\
PI & 2,2200 & 2,5700 & - & - \\
PD & $\mathbf{1 7 9 , 0 0 0 0}$ & - & $\mathbf{2 , 4 6 0 0}$ & - \\
PID & 2,7600 & 3,6900 & 0,5180 & - \\
PDF & $\mathbf{1 3 4 , 0 0 0}$ & - & $\mathbf{2 , 2 9 0 0}$ & $\mathbf{0 , 0 0 0 0 8}$ \\
PIDF & 2,5100 & 3,4500 & 0,3910 & 0,00435 \\
\hline
\end{tabular}

Hasil perhitungan waktu naik respon peralihan tegangan sistem pengatur tegangan otomatis dengan pengendali tunggal dan pengendali kaskade diperlihatkan pada Tabel 5 berikut

Tabel 5, Nilai Waktu Naik Respon Peralihan Sistem Pengatur Tegangan Otomatis

\begin{tabular}{lcc}
\hline \multicolumn{1}{c}{ Pengendali } & $\begin{array}{c}\text { Pengendali } \\
\text { Tunggal }\end{array}$ & $\begin{array}{c}\text { Pengendali } \\
\text { Kaskade }\end{array}$ \\
\hline P & 0,5090 detik & 0,1058 detik \\
I & 3,4950 detik & 3,8258 detik \\
PI & 0,8885 detik & 0,5949 detik \\
PD & $\mathbf{0 , 1 2 2 8 ~ d e t i k ~}$ & $\mathbf{0 , 0 1 3 0 ~ d e t i k}$ \\
PID & 1,0036 detik & 0,7544 detik \\
PDF & $\mathbf{0 , 1 2 2 3}$ detik & $\mathbf{0 , 0 1 2 4}$ detik \\
PIDF & 0,9942 detik & 0,7195 detik \\
\hline
\end{tabular}

Hasil simulasi memperlihatkan bahwa untuk kriteria waktu naik, pengendali yang memenuhi kriteria desain adalah pengendali PD dan pengendali PDF baik untuk pengendali tunggal maupun pengendali kaskade.

Hasil perhitungan waktu puncak respon peralihan tegangan sistem pengatur tegangan otomatis dengan 
pengendali tunggal dan kaskade diperlihatkan pada Tabel 6 berikut

Tabel 6. Nilai Waktu Puncak Respon Peralihan Sistem Pengatur Tegangan Otomatis

\begin{tabular}{lcc}
\multicolumn{3}{c}{ Sistem Pengatur Tegangan } \\
Pengendali & $\begin{array}{c}\text { Pengendali } \\
\text { Tunggal }\end{array}$ & $\begin{array}{c}\text { Pengendali } \\
\text { Kaskade }\end{array}$ \\
\hline P & 1.2086 detik & 0.2437 detik \\
I & 7.5913 detik & 8.7798 detik \\
PI & 1.8092 detik & 1.2478 detik \\
PD & $\mathbf{0 . 2 7 3 9}$ detik & $\mathbf{0 . 0 2 7 5}$ detik \\
PID & 2.2035 detik & 1.6460 detik \\
PDF & $\mathbf{0 . 2 7 4 5}$ detik & $\mathbf{0 . 0 2 6 4}$ detik \\
PIDF & 2.1633 detik & 1.5738 detik \\
\hline
\end{tabular}

Hasil simulasi memperlihatkan bahwa untuk kriteria waktu puncak, pengendali yang memenuhi kriteria desain adalah pengendali PD dan pengendali PDF baik untuk pengendali tunggal maupun pengendali kaskade.

Hasil perhitungan waktu keadaan mantap respon peralihan tegangan sistem pengatur tegangan otomatis dengan pengendali tunggal dan kaskade diperlihatkan pada Tabel 7 berikut

Tabel 7. Nilai Waktu Keadaan Mantap Respon Peralihan Sistem Pengatur Tegangan Otomatis

\begin{tabular}{lcc}
\hline Pengendali & $\begin{array}{c}\text { Pengendali } \\
\text { Tunggal }\end{array}$ & $\begin{array}{c}\text { Pengendali } \\
\text { Kaskade }\end{array}$ \\
\hline P & 2.8265 detik & 0.7973 detik \\
I & 10.9950 detik & 12.3580 detik \\
PI & 4.3429 detik & 2.4037 detik \\
PD & $\mathbf{0 . 5 2 3 0}$ detik & $\mathbf{0 . 0 7 8 8}$ detik \\
PID & 3.4735 detik & 2.8837 detik \\
PDF & $\mathbf{0 . 5 1 5 2}$ detik & $\mathbf{0 . 0 8 2 3}$ detik \\
PIDF & 3.4471 detik & 2.8908 detik \\
\hline
\end{tabular}

Hasil simulasi memperlihatkan bahwa untuk kriteria waktu keadaan mantap, pengendali yang memenuhi kriteria desain adalah pengendali PD dan pengendali PDF baik untuk pengendali tunggal maupun pengendali kaskade.

Hasil perhitungan nilai puncak respon peralihan tegangan sistem pengatur tegangan otomatis dengan pengendali tunggal dan kaskade diperlihatkan pada Tabel 8 berikut

Tabel 8. Nilai Puncak Respon Peralihan Sistem Pengatur Tegangan Otomatis

\begin{tabular}{lcc}
\hline Pengendali & $\begin{array}{c}\text { Pengendali } \\
\text { Tunggal }\end{array}$ & $\begin{array}{c}\text { Pengendali } \\
\text { Kaskade }\end{array}$ \\
\hline P & 0,9597 & 1,0955 \\
I & $\mathbf{1 , 0 7 7 0}$ & $\mathbf{1 , 0 6 8 0}$ \\
PI & 1,0602 & 1,1059 \\
PD & $\mathbf{1 , 0 8 0 4}$ & $\mathbf{1 , 1 1 0 7}$ \\
PID & $\mathbf{1 , 0 6 3 1}$ & $\mathbf{1 , 0 4 7 9}$ \\
\hline
\end{tabular}

\begin{tabular}{lll} 
PDF & 1,0804 & 1,1107 \\
PIDF & 1,0637 & 1,0571 \\
\hline
\end{tabular}

Hasil simulasi memperlihatkan bahwa untuk kriteria nilai puncak, semua jenis pengendali memenuhi kriteria desain baik untuk pengendali tunggal maupun untuk pengendali kaskade kecuali untuk pengendali $\mathrm{P}$ dan pengendali PI tidak memenuhi kriteria desain.

Hasil perhitungan nilai lewatan maksimum respon peralihan tegangan sistem pengatur tegangan otomatis dengan pengendali tunggal dan kaskade ditampilkan pada Tabel 9. Berikut

Tabel 9. Nilai Lewatan Maksiumm respon Peralihan Sistem Pengatur Tegangan Otomatis

\begin{tabular}{lcc}
\multicolumn{3}{c}{ Sistem Pengatur Tegangan } \\
Pengendali & $\begin{array}{c}\text { Pengendali } \\
\text { Tunggal }\end{array}$ & $\begin{array}{c}\text { Pengendali } \\
\text { Kaskade }\end{array}$ \\
\hline P & $22,2310 \%$ & $20,9660 \%$ \\
I & $\mathbf{7 , 6 9 5 3 \%}$ & $\mathbf{6 , 8 0 1 4} \%$ \\
PI & $\mathbf{6 , 0 2 0 9 \%}$ & $\mathbf{1 0 , 5 8 9 0 \%}$ \\
PD & $\mathbf{1 3 , 4 1 1 0} \%$ & $\mathbf{1 1 , 8 6 0 0} \%$ \\
PID & $\mathbf{6 , 3 1 1 3} \%$ & $\mathbf{4 , 7 8 7 1} \%$ \\
PDF & $\mathbf{1 3 , 2 8 8 0} \%$ & $\mathbf{8 , 0 6 6 6} \%$ \\
PIDF & $\mathbf{6 , 3 7 3 9 \%}$ & $\mathbf{5 , 7 1 2 8} \%$ \\
\hline
\end{tabular}

Hasil simulasi memperlihatkan bahwa untuk kriteria nilai lewatan maksimum, semua jenis pengendali memenuhi kriteria desain baik untuk pengendali tunggal maupun untuk pengendali kaskade kecuali untuk pengendali $\mathrm{P}$ tidak memenuhi kriteria desain.

Untuk respon peralihan tegangan sistem pengatur tegangan otomatis tanpa pengendali, dengan pengendali tunggal dan dengan pengendali kaskade untuk tipe pengendali $\mathrm{P}$ ditampilkan pada Gambar 4 berikut

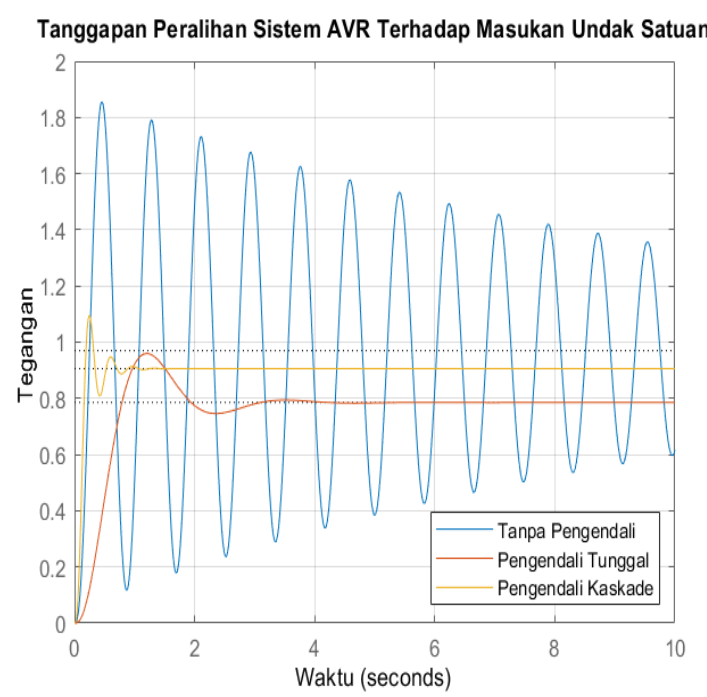

Gambar 4. Respon Peralihan Sistem Pengatur Tegangan Otomatis Terhadap Masukan Undak Satuan 
Untuk respon peralihan tegangan sistem pengatur tegangan otomatis tanpa pengendali, dengan pengendali tunggal dan dengan pengendali kaskade untuk tipe pengendali I ditampilkan pada Gambar 5 berikut

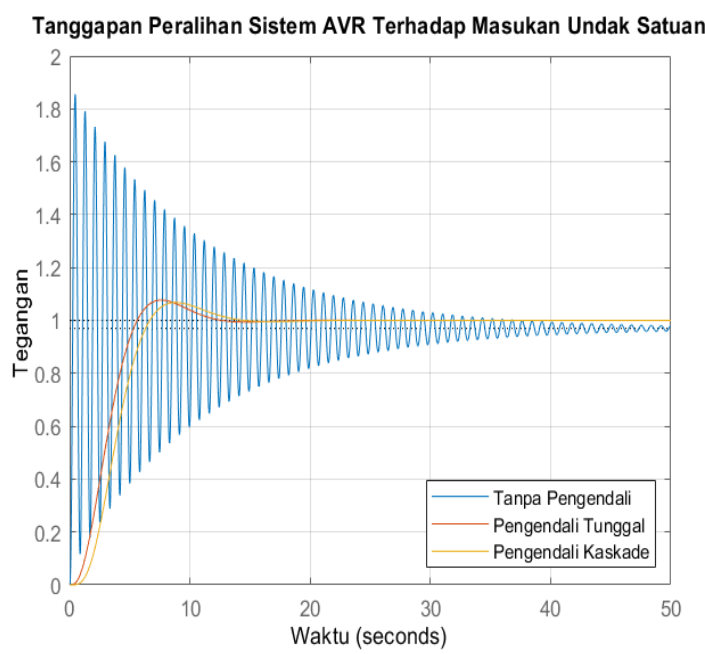

Gambar 5. Respon Peralihan Sistem Pengatur Tegangan Otomatis Terhadap Masukan Undak Satuan

Untuk respon peralihan tegangan sistem pengatur tegangan otomatis tanpa pengendali, dengan pengendali tunggal dan dengan pengendali kaskade untuk tipe pengendali PI ditampilkan pada Gambar 6 berikut

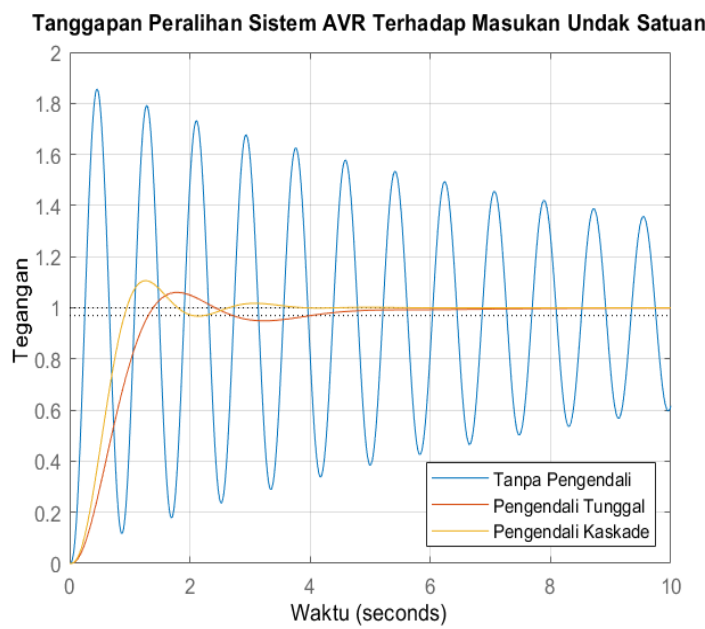

Gambar 6. Respon Peralihan Sistem Pengatur Tegangan Otomatis Terhadap Masukan Undak Satuan

Untuk respon peralihan tegangan sistem pengatur tegangan otomatis tanpa pengendali, dengan pengendali tunggal dan dengan pengendali kaskade untuk tipe pengendali PD ditampilkan pada Gambar 7 berikut

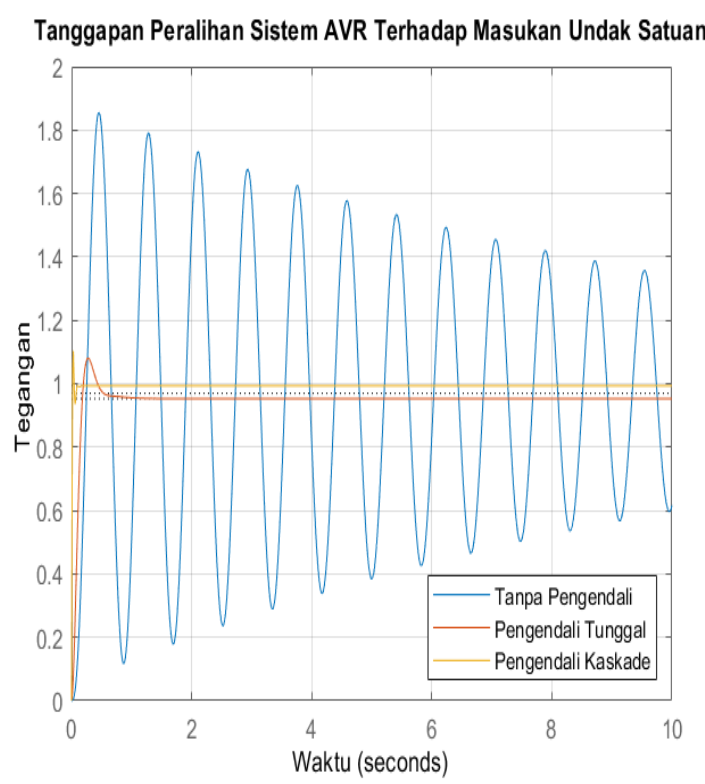

Gambar 7. Respon Peralihan Sistem Pengatur Tegangan Otomatis Terhadap Masukan Undak Satuan

Untuk respon peralihan tegangan sistem pengatur tegangan otomatis tanpa pengendali, dengan pengendali tunggal dan dengan pengendali kaskade untuk tipe pengendali PID d ditampilkan pada Gambar 8 berikut

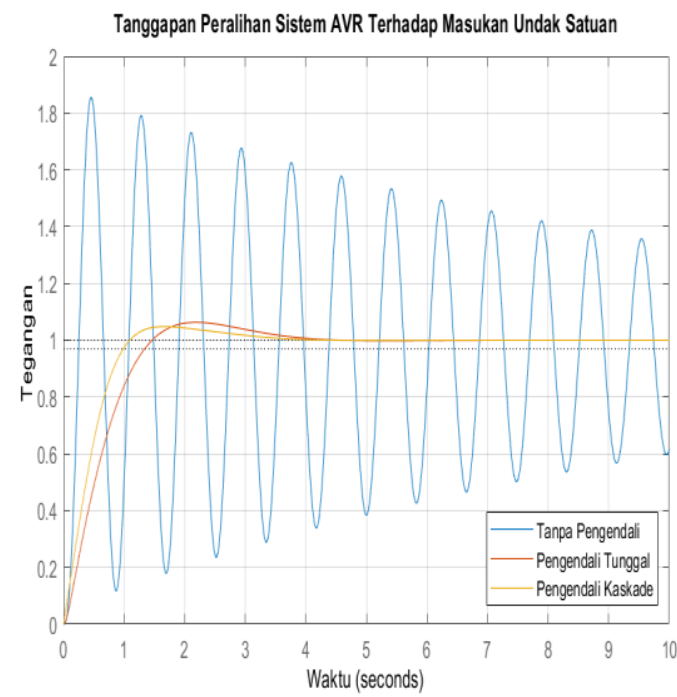

Gambar 8. Respon Peralihan Sistem Pengatur Tegangan Otomatis Terhadap Masukan Undak Satuan

Untuk respon peralihan tegangan sistem pengatur tegangan otomatis tanpa pengendali, dengan pengendali tunggal dan dengan pengendali kaskade untuk tipe pengendali PDF ditampilkan pada Gambar 9 berikut 


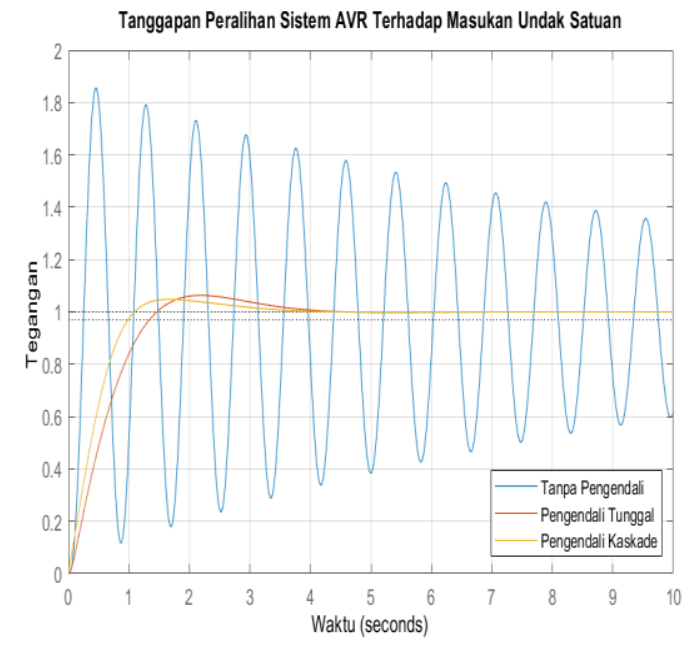

Gambar 9. Respon Peralihan Sistem Pengatur Tegangan Otomatis Terhadap Masukan Undak Satuan

Untuk respon peralihan tegangan sistem pengatur tegangan otomatis tanpa pengendali, dengan pengendali tunggal dan dengan pengendali kaskade untuk tipe pengendali PIDF ditampilkan pada Gambar 10 berikut

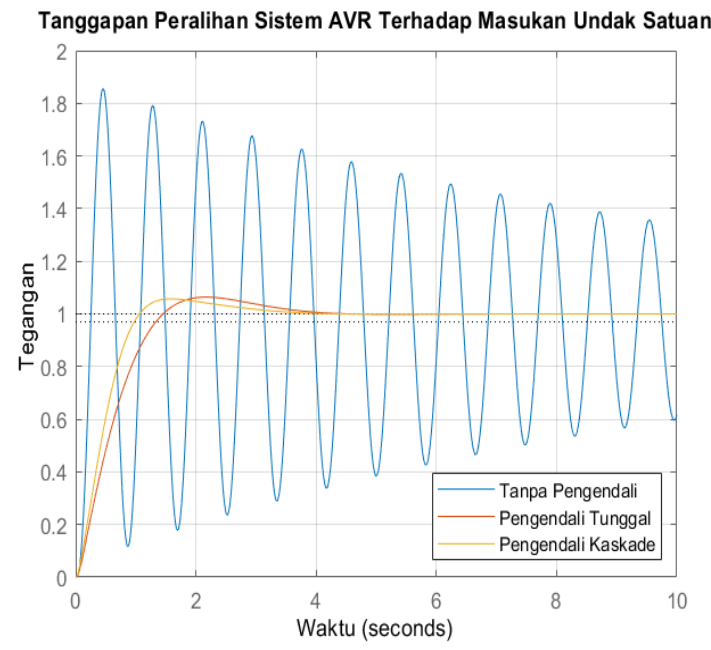

Gambar 10. Respon Peralihan Sistem Pengatur Tegangan Otomatis Terhadap Masukan Undak Satuan

\section{PENUTUP}

\section{A. Kesimpulan}

Adapun kesimpulan dari penelitian ini sebagai berikut

1. Tipe pengendali yang memenuhi kriteria desain untuk sistem pengatur tegangan otomatis adalah pengendali PD dan PDF untuk pengendali tunggal dan pengendali kaskade.

2. Untuk pengendali PD pada pengendali tunggal, nilai konstanta $\mathrm{K}_{\mathrm{p}}$ sebesar 0,6280 dan nilai konstanta $\mathrm{K}_{\mathrm{D}}$ sebesar 0,1710 . Untuk nilai parameter yang diperoleh waktu naik sebesar 0,1228 detik, waktu puncak sebesar 0,2739, waktu keadaan mantap sebesar 0,5229 , nilai puncak sebesar 1,0804 dan nilai lewatan maksimum sebesar 13,4110 persen.

3. Untuk pengendali PDF, nilai konstanta $K_{p}$ sebesar 0,6130 , nilai konstanta $K_{D}$ sebesar 0,1710 dan nilai konstanta $T_{f}$ sebesar 0,0009 . Untuk nilai parameter yang diperoleh waktu naik sebesar 0,1228 detik, waktu puncak sebesar 0,2745 detik, waktu keadaan mantap sebesar 0,5152 detik, nilai puncak sebesar 1,0779 dan nilai lewatan maksimum sebesar 13,2880 persen.

4. Untuk pengendali PD pada pengendali kaskade, nilai konstanta $\mathrm{K}_{\mathrm{p}}$ sebesar 1,7300 dan nilai konstanta $\mathrm{K}_{\mathrm{D}}$ sebesar 0,0242 untuk lingkar dalam $\left(\mathrm{C}_{2}\right)$, Untuk pengendali lingkar luar $\left(\mathrm{C}_{1}\right)$, nilai konstanta $\mathrm{K}_{\mathrm{p}}$ sebesar 179,0000 dan nilai konstanta $\mathrm{K}_{\mathrm{D}}$ sebesar 2,4600 . Untuk nilai parameter yang diperoleh waktu naik sebesar 0,0130 detik, waktu puncak sebesar 0,0275 detik, waktu keadaan mantap sebesar 0,0788 detik, nilai puncak sebesar 1,1107 dan nilai lewatan maksimum sebesar 11,8600 persen.

5. Untuk pengendali PDF pada pengendali kaskade, nilai konstanta $K_{p}$ sebesar 1,5900, nilai konstanta $K_{D}$ sebesar 0,0246, nilai konstanta filter sebesar 0,0018 untuk lingkar dalam $\left(\mathrm{C}_{2}\right)$, Untuk pengendali lingkar luar $\left(\mathrm{C}_{1}\right)$, nilai konstanta $\mathrm{K}_{\mathrm{p}}$ sebesar 134,0000 , nilai konstanta $\mathrm{K}_{\mathrm{D}}$ sebesar 2,2900 dan nilai konstanta filter sebesar 0,00008, Untuk nilai parameter yang diperoleh waktu naik sebesar 0,0139 detik, waktu puncak sebesar 0,0264 detik, waktu keadaan mantap sebesar 0,0823 detik, nilai puncak sebesar 1,0705 dan nilai lewatan maksimum sebesar 8,0666 persen.

\section{B. Saran}

Beberapa saran untuk penelitian selanjutnya adalah

1. Untuk penelitian selanjutnya, analisa peralihan yang dilakukan pada banyak titik operasi sehingga performansi sistem pengatur tegangan otomatis terhadap perubahan parameter dapat diketahui.

2. Dengan adannya analisa pada banyak titik operasi ini sehingga performansi sistem pengatur tegangan otomatis dapat diperbaiki nantinya.

\section{REFERENSI}

[1] Graham, R, "Power System Oscillations", Kluwer Academic Publisher, Massachusetts, 1999.

[2] Sahib, M "A Novel Optimal PID Plus Second Oder Drivative Cntroller for AVR system", Engineering Science and Technology, 194 - 206, 2015.

[3] Bhatt, V, K, \& Bhongade, S, "Design of PID Controller In Pengatur Tegangan Otomatis Using PSO Technique", International Journal of Engineering Research and Applications, 1480 $1485,2013$. 
[4] Saadat, H, "Power System Analysis", McGraw Hill, New York, 1999.

[5] J, Faiz, G,H, Shahgholian \& Arezoomand, M, "Analysis and Simulation of The AVR System and Parameters Variation Effects", Powereng, 450 453, 2017.

[6] Franklin, G,, Powell , J, \& Naeini , A, E, (1986), Feedback Control of Dynamics Systems, New York : Addison - Wesley Publishing Company.
[7] Ogata, K, (2018), Modern Control Engineering , New York : Prentice - Hal.

[8] Laksono, HD (2017), Simulasi dan Analisa Sistem Kendali Dengan Matlab, Studi Kasus : Sistem Automatic Voltage Regulator, Jokjakarta : Teknosain. 